\title{
Effect of Forced-Molting Methods and Rearing Temperatures on The Performance and Organ Biometrics of Laying Hens
}

\section{-Author(s)}

Sgavioli $S$

Filardi R da $\mathrm{S}^{1}$

Praes M F F M ${ }^{1}$

Domingues $\mathrm{CH}^{\mathrm{H}}$ de $\mathrm{F}^{1}$

Andrade $\mathrm{P}$ de $\mathrm{C}^{1}$

Pileggi J1

Boleli I C ${ }^{1}$

Junqueira $\mathrm{O} M$

Universidade Estadual Paulista Júlio de Mesquita Filho, Jaboticabal, SP.

\section{-Mail Adress}

Corresponding author e-mail address

Sarah Sgavioli. Rua Carlos Buck, 313, Santa Tereza, 14883-292. Jaboticabal, SP, Brazil e-mail: sarahsgavioli@yahoo.com.br

\section{घKeywords}

Heat stress, ovary, feed restriction, welfare

' Study funded by Fapesp. Process n.: 07/555970-3, 07/56447-2 e 10/01923-7.

\section{ABSTRACT}

An experiment was conducted to evaluate the biometrics of organs (ovary, oviduct, liver, proventriculus and gizzard) of laying hens submitted to different forced-molting methods of molt and maintained at three different temperature. Organs were evaluated after molting and resting period. Six hundred birds were distributed according to a completely randomized experimental design in a $5 \times 3$ factorial arrangement (forced-molting methods $x$ environmental temperatures) into 15 treatments with 5 replicates of 8 birds each. The molting methods applied were the dietary inclusion of $90 \%$, $70 \%, 50 \%$ of alfalfa, 2,800 ppm zinc oxide, or total feed restriction. Birds were kept at $\pm 20^{\circ} \mathrm{C}, \pm 27^{\circ} \mathrm{C}$, or $\pm 35^{\circ} \mathrm{C}$. Data were submitted to analysis of variance and means were compared by orthogonal and polynomial contrasts. The traditional forced-molting method (feed fasting) resulted in adequate performance. However, as the aim of the present study was to find an alternative method to feed fasting, the highest dietary alfafa inclusion level (90\%) was shown to be efficient compared with other methods, particularly when hens were kept at high temperature. Therefore, this alternative forced-molting may be applied, especially when bird welfare is taken into consideration.

\section{INTRODUCTION}

At the end of the first laying cycle, eggshell thickness and strength are reduced, precisely when egg size is the largest. This problem may be solved by an economically feasible management practice, which is forced molting. Forced molting consists of a set of management practices applied to promote stress, inducing birds to stop producing eggs (Roland \& Brake, 1982).

Several methods to force molting are applied, including feed and water fasting, lighting restriction, and the use of chemical agents. Feed withdrawal from the feeders for 10 to 12 days is the easiest method of inducing molting in layers, resulting in egg production cessation, reproductive tract involution, and feather loss (Brake, 1993). Molting induced by feed fasting causes about $25 \%$ weight loss in layers, and $1 / 4$ of this effect can be directly attributed to reductions in liver, ovary, and oviduct weights (Brake \& Thaxton, 1979).

However, despite being easy to apply and producing the desired results, feed fasting is very aggressive, and therefore, taking into account the importance of animal welfare, molting methods that cause less stress, such as the dietary inclusion of insoluble fiber, have been investigated (Kwon et al., 2001; Donalson et al., 2005; Landers et al., 2005, 2008). 
Sgavioli S, Filardi R da S, Praes M F F M, Domingues $\mathrm{C} H$ de $\mathrm{F}$, Andrade $\mathrm{P}$ de $\mathrm{C}$, Pileggi J, Boleli I C, Junqueira O M

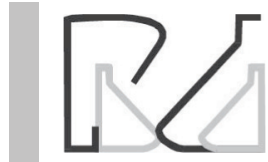

Studies on alternative molting methods have frequently reported conflicting results, which may be attributed to the different environmental conditions in which birds are reared. Among the environmental factors, air temperature, humidity, and movement are highlighted, as they directly affect body temperature maintenance (Tinôco, 1995).

The present study aimed at evaluating the effect of different forced-molting methods applied at three different environmental temperatures on the performance and relative weights of the organs of commercial layers.

\section{MATERIALS AND METHODS}

The experimental period included the periods of molt and rest. Layers were selected according to body weight and egg production. The different methods of forced molting were applied for 14 days, after which there was a 28-day resting period for the recovery of body and organ weights.

In this trial, 600 commercial Isa Brown layers with 72 weeks of age were distributed, according to a completely randomized experimental design with a $5 \times 3$ factorial arrangement (forced molting methods $x$ temperatures) into 15 treatments, with five replicates of eight birds each, totaling 75 experimental units.

During the molting period, a lighting program of $12 \mathrm{~h}$ of light per day was adopted, and the period was light was gradually increased during the resting period until 17 hours of light per day. Feed and water were supplied ad libitum.

Birds were kept in three environmentally-controlled chambers during the molt and the rest periods. Using thermo-hygrometers, the following maximum and minimum temperature and humidity inside the chambers were recorded: $18.9-21^{\circ} \mathrm{C}$ and $41.3-64.4 \%$ in the cold chamber, $25.9-28.5^{\circ} \mathrm{C}$ and $29.5-55.8 \%$ in the thermoneutral chamber, and $29.1-32.4^{\circ} \mathrm{C}$ and $39.9-52.3 \%$ in the hot chamber, respectively.

The following five methods were applied to induce molting: $90 \%$ alfalfa and 10\% feed (A90); 70\% alfalfa and $30 \%$ feed (A70); $50 \%$ alfalfa and $50 \%$ feed (A50); dietary addition of 2,800 ppm zinc (Zn); or feed fasting (control).

The three different environmental temperatures were: cold temperature $(\mathrm{CT}): \pm 20^{\circ} \mathrm{C}$; thermoneutral temperature (NT): $\pm 27^{\circ} \mathrm{C}$; or hot temperature $(\mathrm{HT}): \pm$ $32^{\circ} \mathrm{C}$.

During the experimental period, four birds per treatment were sacrificed after molting and four after
Effect of Forced-Molting Methods and Rearing Temperatures on The Performance and Organ Biometrics of Laying Hens

resting in order to determine relative ovary, oviduct, liver, proventriculus, and gizzard weights.

Feeds were based on corn and soybean meal, and formulated according to the recommendations of Rostagno et al. (2005). (2005).

Table 1 - Ingredient composition of the experimental feeds supplied during the different experimental phases.

\begin{tabular}{lcc}
\hline \multirow{2}{*}{ Ingredients (\%) } & \multicolumn{2}{c}{ Basal diet } \\
\cline { 2 - 3 } & Molting methods & Resting \\
\hline Ground corn & 72.80 & 72.32 \\
Soybean meal 45\% & 23.60 & 23.60 \\
Limestone & 1.54 & 1.54 \\
Dicalcium phosphate & 1.43 & 1.43 \\
Mineral and vitamin & 0.50 & 0.50 \\
supplement* & 0.02 & 0.50 \\
Salt & 0.11 & 0.11 \\
\hline DL-Methionine & 100 & 100 \\
\hline Total & & \\
\hline
\end{tabular}

*Supplied per kg feed: 7,812 IU vitamin A, 3,125 IU vitamin $D_{3}, 15.6 \mathrm{mg}$ vitamin $E_{1} 1.2 \mathrm{mg}$ vitamin $K_{3^{\prime}}, 1.9 \mathrm{mg}$ vitamin $B_{1}, 4.3 \mathrm{mg}$ vitamin $B_{2}, 1.2 \mathrm{mg}$ vitamin $B_{6}, 25$ mcg vitamin $B_{12}, 0.3 \mathrm{mg}$ folic acid, $0.1 \mathrm{mg}$ biotin, $12.4 \mathrm{mg}$ niacin, $0.06 \mathrm{mg}$ calcium pantothenate $9.4 \mathrm{mg}$ copper, $0.8 \mathrm{mg}$ iodine, $57.2 \mathrm{mg}$ manganese, $75.3 \mathrm{mg}$ zinc, $0.3 \mathrm{mg}$ selenium, $0.3 \mathrm{~g}$ choline chloride $50 \%$, $1.8 \mathrm{~g}$ methionine, $62.5 \mathrm{mg}$ growth promoter, $0.5 \mathrm{mg}$ antioxidant.

Table 2 - Nutritional composition of the experimental feeds supplied during the different experimental phases.

\begin{tabular}{lccccc} 
& \multicolumn{5}{c}{ Molting methods } \\
\cline { 2 - 6 } & A90 & A70 & A50 & Zn & Resting \\
\hline $\begin{array}{l}\text { Metabolizable energy } \\
\text { (kcal/kg) }\end{array}$ & 1.184 & 1.592 & 2.000 & 3.025 & 3.008 \\
Crude protein (\%) & 17.00 & 17.00 & 17.00 & 17.00 & 17.00 \\
Crude fiber (\%) & 22.82 & 18.45 & 14.09 & - & - \\
\hline Calcium (\%) & 1.270 & 1.210 & 1.150 & 1.020 & 1.020 \\
Available phosphorus (\%) & 0.110 & 0.170 & 0.230 & 0.380 & 0.380 \\
\hline Total phosphorus (\%) & 0.267 & 0.341 & 0.415 & 0.603 & 0.602 \\
Sodium (\%) & 0.077 & 0.071 & 0.065 & 0.050 & 0.230 \\
\hline Total lysine (\%) & 0.796 & 0.808 & 0.820 & 0.855 & 0.856 \\
\hline Dig. Lysine (\%) & 0.595 & 0.645 & 0.695 & 0.816 & 0.818 \\
\hline Total methionine & 0.264 & 0.292 & 0.320 & 0.389 & 0.390 \\
\hline Dig. methionine (\%) & 0.218 & 0.254 & 0.290 & 0.376 & 0.377 \\
\hline Total met+cys (\%) & 0.466 & 0.518 & 0.570 & 0.698 & 0.698 \\
Dig. met+cys (\%) & 0.428 & 0.484 & 0.540 & 0.680 & 0.680 \\
\hline Total threonine & 0.733 & 0.718 & 0.703 & 0.658 & 0.658 \\
\hline Dig. threonine (\%) & 0.630 & 0.490 & 0.350 & 0.570 & 0.570 \\
\hline Total tryptophan (\%) & 0.258 & 0.234 & 0.210 & 0.151 & 0.151 \\
\hline Dig. tryptophan (\%) & 0.230 & 0.210 & 0.190 & 0.137 & 0.137 \\
\hline
\end{tabular}

${ }^{*} \mathrm{~A} 90=90 \%$ alfalfa and $10 \%$ basal diet; $A 70=70 \%$ alfalfa and $30 \%$ basal diet; $A 50=50 \%$ alfalfa and $50 \%$ basal diet; $Z n=$ basal diet with the addition of 2,800 ppm zinc. 
Sgavioli S, Filardi R da S, Praes M F F M, Domingues $\mathrm{C} \mathrm{H}$ de $\mathrm{F}$, Andrade $\mathrm{P}$ de $\mathrm{C}$, Pileggi J, Boleli I C, Junqueira O M

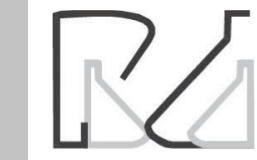

The obtained data were submitted to analysis of variance using the General Linear Models (GLM)

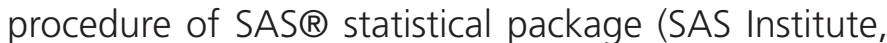
2002). When effect was significant, means were compared, at $5 \%$ probability level, by orthogonal and polynomial contrasts, as contrast 1: comparison between the sum of $A 90, A 70$, and $A 50$ means vs. the sum of $\mathrm{Zn}$ and control (feed fasting) means; contrast 2: linear effect of alfalfa levels; contrast 3: quadratic effect of alfalfa levels; contrast 4: comparison between $\mathrm{Zn}$ and control means; contrast 5: linear effect of temperatures; and contrast 6: quadratic effect of temperatures.

\section{RESULTS AND DISCUSSION}

Ovary weight loss is concomitant with body weight loss, and this process is directly linked to the recovery of the hen's reproductive tract during the molting period (Braker, 1983). Souza et al. (2010) reported that many studies in literature found that reproductive tract involution during molt is required to ensure adequate performance during the second laying cycle. Therefore,

\section{Effect of Forced-Molting Methods and Rearing Temperatures on The Performance and Organ Biometrics of Laying Hens}

morphometric characteristics of some organs of the hens submitted to molting were determined (Tables 3, 4, and 5).

Ovary and oviduct relative weights linearly increased with temperature $\left(p<0.05 ; y=0.0292 x-0.0623, R^{2}=\right.$ $0.80 ; y=0.0378 x+0.6448, R^{2}=0.97$, respectively) as shown in Table 3, with birds maintained at cold temperature presenting the lightest ovaries and oviducts.

The contrast between dietary alfalfa inclusion means and zinc oxide and feed fasting means ( $C 1$ ) was significant $(p<0.05)$ for oviduct relative weight. Average oviduct relative weight of hens submitted to the treatments with alfalfa inclusion (1.82\%) was higher than the average relative weight of hens in the zinc oxide and feed fasting groups (1.46\%), mainly because of the higher oviduct relative weights of hens fed 70 and $50 \%$ of alfalfa $(2.07 \%$ and $1.93 \%$, respectively).

The low feed intake, stress, and nutritional unbalance that result in the involution of the reproductive tract cause a cascade of neuroendocrine effects. Feed fasting or the supply of diets which

Table 3 - Mean relative weight of organs after molting, including probability and contrasts.

\begin{tabular}{|c|c|c|c|c|c|}
\hline \multirow{3}{*}{ Treatments $^{1}$} & \multicolumn{5}{|c|}{ Parameters } \\
\hline & Ovary & Oviduct & Liver & Gizzard & Proventriculus \\
\hline & $(\%)$ & $(\%)$ & $(\%)$ & $(\%)$ & $(\%)$ \\
\hline & \multicolumn{5}{|c|}{ Molting methods (MM)1 } \\
\hline A90 & 0.63 & 1.46 & 1.23 & 2.53 & 0.45 \\
\hline A70 & 0.83 & 2.07 & 1.48 & 2.45 & 0.43 \\
\hline A50 & 0.96 & 1.93 & 1.38 & 2.66 & 0.43 \\
\hline $\mathrm{Zn}$ & 0.59 & 1.37 & 1.49 & 2.63 & 0.53 \\
\hline \multirow[t]{2}{*}{ Feed fasting } & 0.66 & 1.55 & 1.25 & 2.26 & 0.40 \\
\hline & \multicolumn{5}{|c|}{ Temperature $(T)^{1}$} \\
\hline CT & 0.59 & 1.37 & 1.36 & 2.57 & 0.49 \\
\hline NT & 0.60 & 1.72 & 1.43 & 2.50 & 0.44 \\
\hline \multirow[t]{2}{*}{ HT } & 1.02 & 1.94 & 1.32 & 2.45 & 0.42 \\
\hline & \multicolumn{5}{|c|}{$p$ - value at analysis of variance } \\
\hline Molting method & $0.2829 \mathrm{Ns}$ & $0.0340 *$ & $0.4195 \mathrm{NS}$ & $0.0429 *$ & $0.0247^{\star}$ \\
\hline Temperature & $0.0143^{*}$ & $0.0214^{*}$ & $0.6930^{\text {NS }}$ & 0.4835 Ns & 0.0803 NS \\
\hline $\mathrm{MM} \times \mathrm{T}$ interaction & 0.8402 Ns & $0.7863^{N S}$ & $0.4350^{\mathrm{NS}}$ & $0.0895^{N S}$ & 0.4860 NS \\
\hline \multirow[t]{2}{*}{$\mathrm{CV}(\%)$} & 44.33 & 24.25 & 19.90 & 8.73 & 14.23 \\
\hline & \multicolumn{5}{|c|}{$p$ - value for contrasts ${ }^{2}$} \\
\hline C1 & - & $0.0305^{*}$ & - & $0.2084^{\mathrm{NS}}$ & $0.2609 \mathrm{NS}$ \\
\hline C2 & - & 0.0642 Ns & & 0.3321 Ns & 0.7558 NS \\
\hline C3 & - & 0.0779 NS & & $0.2100 \mathrm{NS}$ & 0.8573 NS \\
\hline C4 & - & 0.4585 Ns & & $0.0110^{*}$ & $0.0021 *$ \\
\hline C5 & $0.0099 *$ & $0.0067^{*}$ & & - & - \\
\hline $\mathrm{C} 6$ & 0.1200 NS & 0.6966 Ns & & - & - \\
\hline
\end{tabular}


Table 4 - Mean organ relative weights after resting, including probability and contrasts.

\begin{tabular}{|c|c|c|c|c|c|}
\hline \multirow{3}{*}{ Treatments $^{1}$} & \multicolumn{5}{|c|}{ Parameters } \\
\hline & Ovary & Oviduct & Liver & Gizzard & Proventriculus \\
\hline & $(\%)$ & $(\%)$ & $(\%)$ & $(\%)$ & $(\%)$ \\
\hline & \multicolumn{5}{|c|}{ Molting methods (MM) ${ }^{1}$} \\
\hline A90 & 0.97 & 1.81 & 0.33 & 0.98 & 1.15 \\
\hline A70 & 1.32 & 2.08 & 0.33 & 1.17 & 1.23 \\
\hline A50 & 1.41 & 2.13 & 0.41 & 1.26 & 1.17 \\
\hline $\mathrm{Zn}$ & 1.50 & 2.11 & 0.35 & 1.17 & 1.17 \\
\hline \multirow[t]{2}{*}{ Feed fasting } & 1.35 & 2.09 & 0.31 & 1.30 & 1.15 \\
\hline & \multicolumn{5}{|c|}{ Temperature $(\mathrm{T})^{1}$} \\
\hline $\mathrm{CT}$ & 1.46 & 2.01 & 0.31 & 1.23 & 1.19 \\
\hline NT & 1.24 & 2.13 & 0.37 & 1.19 & 1.26 \\
\hline \multirow[t]{2}{*}{ HT } & 1.23 & 1.99 & 0.35 & 1.11 & 1.07 \\
\hline & \multicolumn{5}{|c|}{$p$ - value at analysis of variance } \\
\hline Molting method & $0.0014^{*}$ & 0.1729 NS & $0.0134^{*}$ & 0.2717 NS & $0.7910^{\mathrm{NS}}$ \\
\hline Temperature & $0.0204^{*}$ & 0.3468 NS & $0.0258 *$ & 0.5461 NS & $0.0066^{*}$ \\
\hline MM $x \mathrm{~T}$ interaction & $0.0007^{*}$ & $0.048^{*}$ & $0.0238^{*}$ & 0.5730 Ns & 0.0573 Ns \\
\hline \multirow[t]{2}{*}{$\mathrm{CV}(\%)$} & 13.80 & 11.60 & 13.26 & 21.27 & 10.01 \\
\hline & \multicolumn{5}{|c|}{$p$ - value for contrasts ${ }^{2}$} \\
\hline C5 & - & - & - & - & $0.0300 *$ \\
\hline C6 & - & - & - & - & $0.0105^{*}$ \\
\hline
\end{tabular}

Ns not significant, ${ }^{*} \mathrm{p}<0.05 .1 \mathrm{~A} 90=90 \%$ alfalfa and $10 \%$ feed, $\mathrm{A} 70=70 \%$ alfalfa and $30 \%$ feed, $\mathrm{A} 50=50 \%$ alfalfa and $50 \%$ feed, $\mathrm{Zn}=$ feed with zinc oxide; $\mathrm{CT}=$ cold temperature; $\mathrm{NT}=$ neutral temperature; $\mathrm{HT}=$ hot temperature. ${ }^{2} \mathrm{C} 5=$ =linear effect of temperature and $\mathrm{C} 6=$ quadratic effect of temperature.

composition does not supply the nutrients required for body maintenance, cause stress and, consequently hypothalamus hyperactivity. The hypothalamus than releases corticotropic (ACTHRF) and thyrotropic (TSHRF) hormones (Girardon, 2011), which act on the pituitary, which then secretes ACTH and TSH. The increase in the blood levels of these hormones leads to adrenal and thyroid hypertrophy and hyperfunction, causing gonadotropic hormone unbalance (Garcia, 2004).

Woodward et al. (2005) fed Leghorn layers a regular feed, $100 \%$ alfalfa or fasted the hens during a 9-day experimental period. The authors observed that ovary weight loss was similar between the fasted and the alfalfa-fed hens. This was also observed by Donalson et al. (2005) and Landers et al. (2005) when comparing feed fasting and feeding $100 \%$ alfalfa as forcedmolting methods. Landers et al. (2008) found a 10fold ovary reduction in commercial layers submitted to forced molting by feeding $100 \%$ alfalfa or feed fasting.

The results of the present study are consistent with literature reports that show that the supply of high fiber levels to induce molting causes similar reproductive tract weight loss as feed fasting (Table 3). According to Landers et al. (2005), in order to be accepted by the poultry industry, methods to induce molting must provide a stimulus substantial enough to cause suficient reproductive tract regression during molting and result in egg production and quality in the second cycle similar to those obtained with the feedfasting method.

The contrast between the zinc oxide and the feed fasting methods was significant $(p<0.05)$ when gizzard and proventriculus relative weights were considered, with heavier weights for the birds fed zinc oxide. These findings are consistent with those reported by Souza et al. (2010), who observed severe gizzard regression and lower gizzard weight when hens were submitted to feed fasting $(1.17 \%)$.

There was no effect of molting method or temperature $(p>0.05)$ on liver relative weight.

Table 4 shows the effects of molting methods applied at different temperatures on ovary, oviduct, liver, gizzard, and proventriculus relative weights of hens sacrificed after the resting period.

Temperature had a quadratic effect $(p<0.05)$ on proventriculus relative weight, which was the heaviest at thermoneutral temperature $\left(y=-0.0022 x^{2}+0.1157 x\right.$ $\left.-0.225 ; R^{2}=0.99\right)$, as shown in Table 4.

Gizzard relative weight was not influenced ( $p>0.05$ ) by molting method or temperature during the resting period.

There was a significant interaction $(p<0.05)$ between treatments in relation to ovary, oviduct, and liver relative weights. 
Sgavioli S, Filardi R da S, Praes M F F M, Domingues $\mathrm{C} \mathrm{H}$ de $\mathrm{F}$, Andrade $\mathrm{P}$ de $\mathrm{C}$, Pileggi J, Boleli I C, Junqueira O M

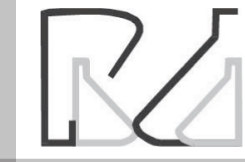

Mean relative weight, $F$ value of orthogonal and polynomial contrasts of the organs that presented significant interaction during the resting period are shown in Table 5.

It was observed that, when hens were kept in the hot temperature environment, the average ovary relative weight of hens fed alfalfa was lower than that of those fed zinc oxide and feed fasted (C1), with $0.95 \%$ and $1.66 \%$, respectively.

\section{Effect of Forced-Molting Methods and Rearing Temperatures on The Performance and Organ Biometrics of Laying Hens}

Also for hens kept at hot temperature, ovary and oviduct relative weights were quadratically $(p<0.05)$ affected by alfalfa levels (C3) with higher relative ovary and oviduct relative weights for molting methods $A 50$ and $A 70$, respectively $\left(y=-0.0009 x^{2}+0.1005 x-\right.$ 1.3738; $R^{2}=0.99, y=-0.0018 x^{2}+0.229 x-4.9225$ $\mathrm{R}^{2}=0.99$, respectively).

When molting methods were considered, temperature had a quadratic effect $(p<0.05)$ on the

Table 5 - Mean relative weight, $\mathrm{F}$ value of orthogonal and polynomial contrasts of the organs that presented significant interaction during the resting period and contrast probabilities.

\begin{tabular}{|c|c|c|c|c|c|c|}
\hline \multirow{2}{*}{$\begin{array}{l}\text { Ovary (\%) } \\
\text { Molting methods (MM)1 }\end{array}$} & \multicolumn{3}{|c|}{ 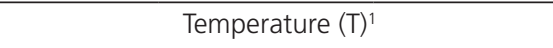 } & \multirow[b]{2}{*}{ Mean } & \multirow[b]{2}{*}{ C5 } & \multirow[b]{2}{*}{ C6 } \\
\hline & $\mathrm{CT}$ & NT & $\mathrm{HT}$ & & & \\
\hline A90 & 1.35 & 1.28 & 0.28 & 0.97 & $0.0003^{*}$ & $0.0020 *$ \\
\hline A70 & 1.52 & 1.25 & 1.19 & 1.32 & 0.3258 Ns & 0.695 Ns \\
\hline A50 & 1.48 & 1.39 & 1.37 & 1.41 & 0.6643 NS & $0.8713^{\mathrm{NS}}$ \\
\hline $\mathrm{Zn}$ & 1.50 & 1.22 & 1.79 & 1.50 & 0.1567 Ns & $0.0501^{*}$ \\
\hline Feed fasting & 1.46 & 1.05 & 1.53 & 1.35 & 0.3618 NS & $0.0051^{*}$ \\
\hline Mean & 1.46 & 1.24 & 1.23 & 1.31 & & \\
\hline C1 & $0.8396^{\mathrm{NS}}$ & $0.0703^{\mathrm{NS}}$ & $0.0005^{\star}$ & & & \\
\hline C2 & $0.5933^{\mathrm{NS}}$ & $0.3863^{\mathrm{NS}}$ & $0.0006^{*}$ & & & \\
\hline C3 & $0.6313^{\mathrm{NS}}$ & $0.4358^{\mathrm{NS}}$ & $0.0305^{*}$ & & & \\
\hline C4 & $0.8812^{\mathrm{NS}}$ & $0.2025^{\mathrm{NS}}$ & $0.1304^{\mathrm{NS}}$ & & & \\
\hline Oviduct (\%) & & emperature & & & & \\
\hline Molting methods (MM) 1 & $\mathrm{CT}$ & NT & HT & Mean & C5 & $\mathrm{C} 6$ \\
\hline A90 & 1.87 & 2.26 & 1.31 & 1.81 & 0.0829 NS & $0.0371 *$ \\
\hline A70 & 1.85 & 1.97 & 2.41 & 2.08 & 0.1232 Ns & 0.5214 NS \\
\hline A50 & 2.17 & 2.14 & 2.09 & 2.13 & $0.6517^{\text {NS }}$ & 0.9395 Ns \\
\hline Zn & 2.01 & 2.23 & 2.07 & 2.11 & 0.7269 Ns & 0.2457 Ns \\
\hline Feed fasting & 2.17 & 2.07 & 2.03 & 2.09 & $0.7333^{\mathrm{NS}}$ & 0.9269 NS \\
\hline Mean & 2.01 & 2.13 & 1.99 & 2.04 & & \\
\hline C1 & $0.5744^{\mathrm{NS}}$ & $0.7776^{\mathrm{NS}}$ & $0.4244^{\mathrm{NS}}$ & & & \\
\hline$C 2$ & $0.3979^{\text {NS }}$ & $0.4644^{\text {NS }}$ & $0.1112^{\mathrm{NS}}$ & & & \\
\hline C3 & $0.5940^{\mathrm{NS}}$ & $0.1401^{\mathrm{NS}}$ & $0.0033^{*}$ & & & \\
\hline C4 & $0.6533^{\mathrm{NS}}$ & $0.3260^{\text {NS }}$ & $0.8683^{\mathrm{NS}}$ & & & \\
\hline Liver (\%) & & emperature & & & & \\
\hline Molting methods (MM) ${ }^{1}$ & $\mathrm{CT}$ & NT & $\mathrm{HT}$ & Mean & $\mathrm{C} 5$ & C6 \\
\hline A90 & 0.27 & 0.42 & 0.29 & 0.33 & 0.5157 Ns & $0.0044^{*}$ \\
\hline A70 & 0.49 & 0.29 & 0.39 & 0.33 & 0.0652 Ns & $0.1683^{\text {NS }}$ \\
\hline A50 & 0.41 & 0.45 & 0.37 & 0.41 & 0.4642 Ns & 0.2107 Ns \\
\hline Zn & 0.27 & 0.43 & 0.37 & 0.35 & $0.2155^{\text {NS }}$ & 0.1218 Ns \\
\hline Feed fasting & 0.31 & 0.28 & 0.34 & 0.31 & 0.6455 Ns & 0.4425 Ns \\
\hline Mean & 0.31 & 0.37 & 0.35 & 0.34 & & \\
\hline C1 & $0.3143^{\mathrm{NS}}$ & 0.2093 Ns & 0.9807 Ns & & & \\
\hline C2 & 0.0450 * & 0.4187 Ns & 0.1557 NS & & & \\
\hline $\mathrm{C} 3$ & $0.0329^{*}$ & $0.0044^{*}$ & 0.2154 Ns & & & \\
\hline C4 & $0.4667^{\mathrm{NS}}$ & $0.0070^{*}$ & 0.6441 Ns & & & \\
\hline
\end{tabular}

${ }^{\text {Ns }}$ not significant, ${ }^{*} p<0.05 .1 \mathrm{~A} 90=90 \%$ alfalfa and $10 \%$ feed, $\mathrm{A} 70=70 \%$ alfalfa and $30 \%$ feed, $A 50=50 \%$ alfalfa and $50 \%$ feed, $\mathrm{Zn}=$ feed with zinc oxide; $C \mathrm{CT}=$ cold temperature; $\mathrm{NT}=$ neutral temperature; $\mathrm{HT}=$ hot temperature. $\mathrm{C} 1=$ means of treatments with alfalfa versus means of the other treatments (zinc oxide and feed fasting); $\mathrm{C}=$ =linear effect of alfalfa levels; $\mathrm{C} 3=$ quadratic effect of alfalfa levels; $\mathrm{C} 4=$ comparison between zinc and feed fasting; $\mathrm{C} 5=$ linear effect of temperature; and $\mathrm{C} 6=$ quadratic effect of temperature. 
Sgavioli S, Filardi R da S, Praes M F F M, Domingues $\mathrm{C} H$ de $\mathrm{F}$, Andrade $\mathrm{P}$ de $\mathrm{C}$, Pileggi J, Boleli I C, Junqueira O M

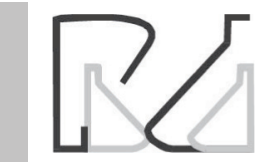

ovary and oviduct relative weights of birds fed $90 \%$ alfalfa, with higher ovary and oviduct relative weights (y $=-0.0077 x^{2}+0.3503 x-2.59 ; R^{2}=0.99, y=-0.0116 x^{2}$ $+0.6024 x-5.525 ; R^{2}=0.99$, respectively) obtained in hens kept at thermoneutral temperature.

When molting was induced with zinc oxide and feed fasting, temperature had a quadratic effect on ovary relative weight $\left(p<0.05 ; y=0.0074 x^{2}-0.3886 x\right.$ $+6.305 ; R^{2}=0.99, y=0.0079 x^{2}-0.4301 x+6.9 ; R^{2}$ $=0.99$, respectively), with the heaviest ovary relative weight obtained in hens kept in the hot temperature environment.

The recovery of the reproductive tract after the resting period is extremely important for egg production during the second laying cycle. One of the main functions of the ovary is to produce steroidal hormones, which are essential for reproductive tract growth and function and depend on the bird's nutritional status. The reproductive system is regulated by the hypothalamic-pituitary-gonadal axis. The gonadotropin-releasing hormone $(\mathrm{GnRH})$ stimulates the pituitary to secrete the luteinizing hormone $(\mathrm{LH})$, which is responsible for stimulating progesterone production by the mature follicle that consequently breaks and releases the ovum. The pituitary also produces the follicle-stimulating hormone (FSH). FSH may stimulate the production of steroidal hormones by the developing follicle cell, particularly in the small follicles (Leite \& Viveiros, 2009).

The details of the interactions found in the present study showed that, when hens are maintained at hot temperature, the most efficient molting methods in terms of recovery of the reproductive tract were A50, A70, zinc oxide, and feed fasting, whereas when temperature was thermoneutral, A90 promoted the best recovery of the ovary and of the oviduct.

There is little information in literature describing the effects of alternative molting methods on the recovery of organs after the resting period, particularly when different environmental temperatures were used.

There was a quadratic effect $(p<0.05)$ of the interaction (C3) of cold temperature with dietary alfalfa levels $\left(y=-0.0004 x^{2}+0.049 x-1.1025 ; R^{2}\right.$ $=0.99$ ), with hens submitted to molting methods A70 and A50 presenting the heaviest livers. When birds were kept at thermoneutral temperature, the contrast among alfalfa levels (C3) had a quadratic effect $(p<0.05)$ on liver relative weight $\left(y=0.0004 x^{2}-\right.$ $\left.0.0515 x+2.1187 ; R^{2}=0.99\right)$, with birds submitted to $A 90$ and $A 50$ presenting heavier livers. Also when kept under thermoneutral temperature, when the methods
Effect of Forced-Molting Methods and Rearing Temperatures on The Performance and Organ Biometrics of Laying Hens

of feed fasting and zinc oxide were compared, hens submitted to the zinc oxide method presented higher liver relative weight $(p<0.05)$.

Considering the molting methods applied, only liver relative weight of hens submitted to $A 90$ was influenced by temperature $(p<0.05 ; y=-0.0025 \times 2+$ $\left.0.1395 x-1.515 ; R^{2}=0.99\right)$, with the heaviest livers obtained at thermoneutral temperature.

Better liver weight recovery indicates that more energy sources, such as glycogen and lipids, are being metabolized in the liver (Berry \& Brake, 1985). Liver recovery is also an indication that the hormones required for egg production after molting are being produced. Egg production depends on ovarian steroids (Berry \& Brake, 1985), such as estrogen, which stimulate yolk production through the synthesis of phosphoproteins that are produced in the liver (Berry \& Brake, 1985). Therefore, when hens were submitted to different forced-molting methods and kept at thermoneutral temperature, the method of the dietary inclusion of 90\% alfalfa promoted the best liver recovery, which may aid egg production during the second laying cycle.

\section{CONCLUSIONS}

The traditional forced-molting method of feed fasting resulted in good performance. However, as the purpose of the present study was to find an alternative method to feed fasting, the dietary inclusion of the highest alfalfa level, that is, the supply of $90 \%$ alfalfa and $10 \%$ feed was shown to be efficient compared with the other tested methods, particularly when birds were kept under hot temperature. Therefore, the dietary inclusion of $90 \%$ alfalfa may be used as an alternative forced-molting method relative to feed fasting, especially when bird welfare is taken into consideration.

\section{REFERENCES}

Berry WD, Brake J. Comparison of parameters associated with molt induced by fasting, zinc and low dietary sodium in caged layers. Poultry Science $1985 ; 64: 2027-2036$

Brake J, Thaxton P. Physiological changes in caged layers during a forced molt. Poultry Science 1979;58:707.

Brake J. Recents advances in induced molting. Poultry Science 1993;72:929931

Donalson LM, et al. Utilizing different ratios of alfalfa and layer ration for molt induction and performance in commercial laying hens. Poultry Science 2005;84:362-369.

Garcia EA. Muda forçada em poedeiras comerciais e codornas. Anais da Conferência Apinco de Ciência e Tecnologia Avícolas; 2004; Santos, São Paulo. Brasil. p.45-62 
Girardon JC. Métodos nutricionais de muda forçada em poedeiras semipesadas[dissertação]. Pelotas(RS): UniversidadeFederal de Pelotas; 2011.

Kwon YM, et al. Use of an alfalfa diet for molting in leghorn hens to reduce Salmonella enteritidis colonization and invasion [abstr]. Poultry Science 2001;80(Suppl.1):90

Landers $\mathrm{KL}$, et al. Alfalfa as a single dietary source for molt induction in laying hens. Bioresource Technology 2005;96:565- 570

Landers $\mathrm{KL}$, et al. Organ weight and serum triglyceride responses of older (80 week) commercial laying hens fed an alfalfa meal molt diet. Bioresource Technology 2008;99:6692-6696.

Leite MA da S, Viveiros AT de M. Coleta de sêmen e inseminação artificial em galinhas. [Boletim Técnico 71]. Lavras: Universidade Federal de Lavras; 2009. p.1-19.

Roland DA, Brake JH. Influence of premolt production on postmolt performance with explanation for improvement in egg production due to force molting. Poultry Science 1982;61(12):2473-2481.
Rostagno HS, et al. Tabelas brasileiras para aves e suínos: composição de alimentos e exigências nutricionais. $3^{a}$ ed. Viçosa: UFV; 2005

SAS Institute. SAS ${ }^{\circledR}$ user' guide: statistics. Cary; 2002.

Souza KMR, Carrijo AS, Allaman IB, Fascina VB, Mauad JRC, Suzuki FM Métodos alternativos de restrição alimentar na muda forçada de poedeiras comerciais. Revista Brasileira Zootecnia 2010;39(2):356-362.

Tinôco IFF. Estresse calórico - meios naturais de condicionamento. Anais do Simpósio Internacional sobre Ambiencia e Instalação na Avicultura Indutrial; 1995; Curitiba, Paraná. Brasil: Campinas: Facta; 1995. p.99108.

Woodward CL, et al Reduction of Salmonella enterica serovar Enteritidis colonization and invasion by an alfalfa diet during molt in Leghorn hens. Poultry Science 2005;84:185-193. 
